\title{
The Cost of Antidumping: The Devil is in the Details
}

\author{
Bruce A. Blonigen \\ University of Oregon and NBER
}

\author{
Thomas J. Prusa \\ Rutgers University and NBER
}

\begin{abstract}
In this paper we argue that the costs of antidumping (AD) protection are substantially higher than standard tariff analysis would suggest. First, we argue that because AD duties are often adjusted during administrative reviews the welfare cost of AD duties increases over time. These adjustments effectively transfer heavily distorted AD revenue to foreign firms. Such transfers are especially costly in light of the fact that foreign firms have little scope to adjust their destination market prices. Second, we argue that AD duties are more costly than simply the visible costs of $\mathrm{AD}$ protection. There are significant additional costs associated with the prospect of protection and these costs are imposed on both the domestic economy and on the international trading community. These costs are created when foreign and domestic firms alter their standard profit maximizing behavior in order to influence the outcome of potential AD investigations. Although these costs cannot be measured, they may easily exceed the direct cost of AD duties.
\end{abstract}

\section{JEL classification: F13.}

\footnotetext{
*Blonigen's address: Department of Economics, 1285 University of Oregon, Eugene, OR 97403; Email: bruceb@oregon.uoregon.edu; Ph: 541-346-4680. Prusa's address: Department of Economics, Rutgers University, 75 Hamilton St., New Brunswick, NJ, 08901; Email: prusa@economics.rutgers.edu; Ph: $732-$ 932-7670.
} 


\section{Introduction.}

Against the backdrop of substantial cuts in worldwide tariffs and quantitative restrictions from a successful GATT Uruguay Round has been a disturbing trend of rapid growth in a new and virulent strain of trade protectionism called antidumping (AD) protection. AD protection allows countries to levy a duty on foreign firms when it is determined that these firms are selling their goods in the country at an "unfair" price and this is causing "material injury" to the country's domestic firms that compete in the same market. As documented by Prusa (2001), the number of countries administering AD protection nearly tripled from the 1980s to the 1990s, with twenty-nine different countries initiating AD investigations during the period from 19871997. While the traditional users of AD laws (Australia, Canada, the EU, and the U.S.) continued similar levels of AD use over the past decades, AD use by "new" users increased fivefold from 1987-1997, and has accounted for approximately half of all AD investigations since 1995. Rather than take measures to reduce AD protection, the Uruguay Round arguably helped accelerate its use by further codifying accepted AD use, thus providing a template for any WTO country to implement AD laws that are WTO-consistent. Despite the increase in the number of $\mathrm{AD}$-using countries, the traditional users (particularly the U.S.) remain staunch defenders of current AD laws and practices. In many ways this is ironic, since the U.S. often professes to be the main proponent of further trade liberalization within WTO.

An important rationale for the WTO to allow AD protection is that "unfair" trade practices could undermine and distort competitive and well-functioning markets, leading to inefficiencies. Putting in place a system by which countries can punish such activity with duties to counteract these unfair trade practices, similar to allowing countervailing duties on export subsidies, seems reasonable. Thus, the U.S. position may not be ironic at all. While this 
rationale may seem plausible, the devil is in the details of how AD laws and investigations are determined and structured. And that devil, as we discuss in this paper, is telling us that AD laws are about trade protection, not correcting anticompetitive behavior. In addition, this paper will also explain how the very intricate and complicated process surrounding AD investigations and determinations leads to costs of $\mathrm{AD}$ protection that likely go well beyond more traditional forms of import protection.

\section{The Disconnect Between Competition Policy and AD Protection.}

There has been more than a century of legal analysis of what constitutes anti-competitive behavior through application of antitrust laws. Yet, the definition of "unfair" trade practices and application of antidumping remedies has been allowed to develop a life of its own and bears no resemblance to established standards of anti-competitive behavior. The anti-competitive practice most relevant to our AD discussion here is predatory pricing. This is where a firm prices low with the intent of driving rivals out of business. The standard for judging whether a firm is pricing in such a manner is to examine whether a firm's price falls below its marginal cost. Since marginal cost is essentially unobservable, Areeda and Turner (1975) have alternatively suggested looking at whether price is below average variable cost; i.e., excluding fixed costs.

As mentioned in the introduction, dumping is simply defined as the practice of a firm selling at a price in its export market that is below "fair" value. Application of this definition is not so simple as it involves a more precise definition of "fair". In practice, two main ways have evolved to calculate "fair" value: 1) The price charged by the exporting firm in its own market for the same product, or 2) the cost of the product constructed from firm-level accounting data. ${ }^{1}$

\footnotetext{
${ }^{1}$ The cost-based definition of dumping was only codified into GATT AD rules during the Tokyo Round. This amendment was demanded by domestic industries (most notably steel) in order to make AD more
} 
Both of these definitions are very weak in terms of identifying economic behavior that could be considered anti-competitive; i.e., the criteria to judge whether predatory pricing is occurring. Under the first definition, a firm is dumping simply by price discriminating; i.e., charging different prices in different markets. It is virtually impossible to find a market in which firms are not price discriminating in some way and antitrust laws do not deem this practice as anti-competitive per se. ${ }^{2}$ If countries do not worry about price discrimination by firms for different consumers in the domestic economy, why should we worry about it across national borders?

The second definition of "fair" value leads to an even more ridiculous criterion by antitrust standards. As mentioned, antitrust authorities do worry about pricing below marginal cost (or, in practice, average variable cost), as this has become the standard for believing that the firm is not maximizing short-run profits, but instead pricing in a predatory fashion to drive out rivals. In fact, one can see that relaxing standards to prosecute any firm that prices below average total cost (including fixed costs) for antitrust violations is ridiculous. This would mean that one could prosecute any firm that is making a loss. Yet, when many countries' antidumping authorities determine "fair value" through "constructed cost" measures, they not only include fixed costs, but they also add on their own estimate for what should be a normal profit for the firm in the market. As a result, they take the ridiculous to another level and convict a foreign firm for not making enough economic profit from a country's consumers.

protective. As Messerlin (1989), Clarida (1996), and Lindsey (1999) have reported, US and EU AD disputes are now being dominated by cost-based allegations. Such trends have led one noted legal expert to claim that cost-based AD petitions have become "the dominant feature of US antidumping law" (Horlick, 1989, p. 136).

${ }^{2}$ In other words, it's mere existence is not enough to rule the behavior illegal. It must be shown that the practice is intended to harm competition. Viscusi et al. (1995) conclude that the enforcement of the U.S. Robinson-Patman Act against price discrimination for cases where it was a potentially anticompetitive 
Under WTO rules, affirmative AD determinations with resulting AD duties, require a finding of not only dumping, but also material injury (or threat of injury) to the domestic firm due to import competition. Of course, saying that having a foreign competitor in the market place is injurious to a domestic firm is like saying that water is wet. Competition reduces current firms' profitability, which is an indication of efficient markets. The criterion of "material" injury only raises the bar slightly by ruling out trivially small competitors. With that said, the criterion in practice is to examine whether there have been substantial increases in import competition that correlate with declines in domestic firms' profitability. While this proves to be a tougher hurdle to cross, such marketplace occurrences have no necessary correlation with anti-competitive practices.

In the end, the term "unfair" has evolved to mean something completely different in the practice of $\mathrm{AD}$ protection than standard notions of "anti-competitive." As such, there is a very large disconnect between AD protection and the competition policy of developed countries. Any changes in the market place that lead to less favorable outcomes for the domestic firm are considered unfair, so that $\mathrm{AD}$ laws are truly about protecting domestic firms' interests, not competition. This places us back into the familiar realm of "beggar-thy-neighbor" trade policies, with many of the well-known economic welfare consequences. However, it is worse than this. As we will show below, the complex institutions and procedures surrounding AD investigations, determinations, and administration of the AD duties after the case lead to a myriad of additional unintended consequences that likely make such trade protection more onerous than other forms. In fact, one of the ironies is that the economic literature has shown that $\mathrm{AD}$ laws likely help facilitate anti-competitive behavior on the part of firms.

behavior actually led to anticompetitive results and conclude, "Fortunately, enforcement by the Federal Trade Commission has declined in recent years." (p. 298) 
In the rest of the paper we discuss the many potential costs of $\mathrm{AD}$ protection as currently practiced under WTO rules. In the next section, we explain the costs connected with the AD duties. While there are some similarities to the standard economic welfare analysis of an ad valorem tariff, there are important differences connected with the administration of the $\mathrm{AD}$ duties after the case that have been shown to that substantially increase the cost of AD duties. We then examine the costs associated with the AD investigation itself and its effect on firms' behavior that leads to the potential for significant additional costs, even when we may not observe $\mathrm{AD}$ investigations and duties. In other words, even the threat of $\mathrm{AD}$ investigations and duties can lead to distorted market behavior and costly inefficiencies. In the process, the reader will hopefully get a brief overview of the relevant economics literature on AD protection.

\section{The Cost of AD Duties.}

Before discussing the cost of $\mathrm{AD}$ duties, it is instructive to review the standard analysis of the costs of import tariffs and quotas for comparison purposes. The economic consequences of an import tariff are well-known. The tariff leads to a higher price in the importing country that creates gains for the domestic producers at the expense of consumers, while the government collects tariff revenues and can then redistribute to the general population. If markets are perfectly competitive and the importing country is small enough in the world that the import tariff will not significantly affect world price of the good, then the welfare effect for the importing country is an unambiguous net loss. Simply put, the gains to the producers plus the tariff revenue cannot outweigh the losses to consumers from higher prices. In the end, there is nothing to counteract the efficiency loss from the consumers that completely stop purchasing the product (no purchase means no tariff revenue can be collected). Nor is there anything to 
counteract the replacement of production by less-efficient producers in the importing country for some of the more-efficiently produced imports. If the importing country is large enough that its import tariff (and accompanying reduced world demand) reduces the price, it can experience a "terms-of-trade" gain that may counteract these losses and become a net gain. However, this is a theoretical construct that seems far afield from why countries impose import tariffs.

For any given import tariff, one can set up an import quota that yields identical price and quantity effects in the marketplace assuming markets are perfectly competitive. However, the main difference is that the government will not collect any tariff revenue. Instead, the price increase on imports will accrue to the foreign producers, not the importing country, unless the importing country takes certain actions to reacquire these rents. ${ }^{3}$ In practice, the rents almost always are allowed to accrue to the foreign firms and the importing country's welfare is worse off than an import tariff by these lost quota rents. ${ }^{4}$

Because affirmative AD investigations lead to ad valorem duties, it is easy to assume that the economic welfare consequences of AD duties are identical to an import tariff. In fact, a number of studies have treated AD duties as standard import tariffs and estimated their welfare consequences using computable partial equilibrium models of the affected markets. ${ }^{5}$ The most comprehensive of these studies is Kelly and Morkre (1998), which examines the welfare consequences of the vast majority of U.S. AD/CVD cases from 1980 through 1988. Treating

\footnotetext{
${ }^{3}$ Such actions include auctioning off import licenses in which case the government would generate auction revenues equivalent to the quota rents assuming an efficient auction or giving the import licenses to domestic importers so that they, not the foreign firms, accrue the quota rents.

${ }^{4}$ There is a substantial literature on the nonequivalence of import tariffs and quotas for a variety of settings, most of which involve imperfectly competitive markets. However, regardless of the setting, allowing quota rents to accrue to the foreign firms, rather than collecting the tariff revenue clearly means the importing country is made worse off in this dimension with a quota.

${ }^{5}$ These papers include Murray and Rousslang (1989), Morkre and Kelly (1994), DeVault (1996), and Kelly and Morkre (1998). Another set of papers, including Hartigan et al. (1989), Mahdavi and Bhagwati (1994) and Hughes et al. (1997), have examined the effect of AD investigation events on stock market
} 
AD duties as standard import tariffs, they find that the welfare effects for U.S. AD duties during this period are generally quite small.

On one hand, Kelly and Morkre's conclusion may not be surprising, as AD actions are often targeted at very select products. On closer inspection though, there are a number of characteristics of $\mathrm{AD}$ law and the administration of $\mathrm{AD}$ duties that mean this standard analysis is not complete. One important difference is that AD duties are not fixed. They are potentially recalculated over time to adjust $\mathrm{AD}$ duties as foreign firm dumping behavior changes. This is called an administrative review process. USITC (1995) and Gallaway et al. (1999) show that the administrative review process connected with $\mathrm{AD}$ duties has drastic consequences for the welfare effects of $\mathrm{AD}$ duties in relation to an import tariff. The rationale for such a conclusion is the following. Evidence suggests that foreign firms often respond to AD duties by raising their prices to the importing country because of the administrative review process. This reduces the calculated dumping margin and leads to lower future AD duties for the firm. Thus, the practice of administrative review allows the foreign firms to effectively divert tariff revenue from the importing country to rents for the foreign firm, analogous to the rents lost when imposing a quota, rather than an import tariff.

Using data on all U.S. AD/CVD cases in place as of 1993, Gallaway et al. (1999) show that this transfer allowed through administrative reviews of AD duties means a much more substantial loss to the U.S. than if AD duties were just standard tariffs. Using a computable general equilibrium model of the 1993 U.S. economy, they find that if one only estimates the effect of the $\mathrm{AD}$ duties that are observed in 1993, the net welfare loss to the U.S. is \$209 million annually. However, when one takes into account the previous recalculations that had occurred

reactions with respect to domestic firms' stock price, which indicates expected changes in firm profitability. 
through administrative reviews, the welfare loss for the U.S. is an order of magnitude larger, with a range of \$2-4 billion annually! Their model also estimates that the U.S. AD/CVD duties "saved" 14,250 jobs in import-competing sectors annually, which translates into a range of $\$ 161,000$ to $\$ 281,000$ per job "saved." The word "saved" is in quotation marks because presumably workers displaced from import-competing sectors are not lost to the economy, but will ultimately relocate to industries that are more competitive. And, in general, importcompeting sectors pay below average wages.

In summary, the recalculation of $\mathrm{AD}$ duties through the administrative review process leads to drastically larger welfare costs for the country that imposes such duties. From a worldwide perspective, this is not as serious for welfare as it is for the importing country, since the recalculation effect simply involves a transfer from the importing country to the foreign firms. Then we are back to the $\$ 209$ million annual figure from efficiency losses in the importing country plus the efficiency losses from the foreign supply side. ${ }^{6}$ However, as the rest of the paper details, these costs which economists are adept at estimating may pale in comparison to other sources of welfare losses that are much more difficult to quantify.

For example, if markets are imperfectly competitive, the administrative review process may help facilitate collusion among the domestic and foreign firms. Given a specified AD duty and the administrative review process, domestic firms have a good indication that foreign firms' prices will go up and even may indicate how much they will go up. This may allow the domestic and foreign firms to coordinate their actions, leading to much higher prices and domestic firm profits. This is one explanation for why importing countries allow recalculation of duties, even if this means lost revenue from duty collection. Their goal is simply to increase domestic firms' 
profitability. In contrast, antitrust laws try to prevent coordination of prices because the increase in prices and market power can lead to substantial consumer surplus losses, much more substantial than the normal losses associated with imposing trade protection in perfectly competitive markets. ${ }^{7}$

The welfare estimates calculated by Gallway et al. (1999) do not address a number of other costs of $\mathrm{AD}$ duties that are difficult to observe and estimate. One such cost is the possibility of retaliation. U.S. AD actions against Canada may lead to retaliatory Canadian AD (or other trade protection) actions against U.S. exporters, compounding the losses due to trade protection. The spread of antidumping use across WTO countries makes this a particularly relevant concern and Prusa and Skeath (2001) have found evidence of worldwide "tit-for-tat" AD filing behavior. ${ }^{8}$ In a related vein, $\mathrm{AD}$ protection in an upstream industry raises prices for downstream industries, which may to lead to AD petitions and duties in these downstream industries. Feinberg and Kaplan (1993) find evidence for this spreading of AD protection downstream in U.S. AD petition filings.

Another cost not contained in the Gallaway et al. welfare estimates is the domestic industry's rent-seeking costs. The standard estimate is that legal fees for pursuing an $\mathrm{AD}$ investigation in the U.S. ranges from $\$ 250,000$ to $\$ 1$ million. This is for the initial case and does not include fees incurred for each annual administrative review. However, studies of U.S. agency AD decisions find evidence that political influence is an important determinant. For

${ }^{6}$ Gallaway et al. (1999) only model the effect of U.S. AD/CVD duties on U.S. welfare. As Feenstra (1992) points out, the efficiency losses on the foreign supply side from import protection programs can easily rival those on the domestic import side.

${ }^{7}$ Below we discuss how collusion may be facilitated even by the initiation of an AD investigation.

${ }^{8}$ On the other hand, Blonigen and Bown (2001) point out that the increasing potential for retaliation may have a dampening effect on worldwide activity, similar to a cold war equilibrium between countries with nuclear weapons. They find evidence in U.S. AD filings that domestic firms are less likely to file cases 
example, Hansen and Prusa $(1996 ; 1997)$ show that Political Action Committee (PAC)

contributions to influential congressmen lead to a greater likelihood of an affirmative AD

decision for a domestic industry. ${ }^{9}$ The funds used in these rent-seeking activities are inefficient

in that they could have been used for productive uses by the domestic industry. For example, there is concern that firms receiving trade protection do not innovate as much as they would under free trade..$^{10}$

\section{The Cost of the Prospect of AD Duties.}

In the previous section we emphasized the costs of imposing $\mathrm{AD}$ duties, and in a very real sense, duties are the direct, visible cost of $\mathrm{AD}$ protection. AD duties and the costs associated with their imposition can be measured. There is, however, a growing recognition that the real costs of $\mathrm{AD}$ protection are far greater and more widespread than simply the costs incurred in those cases that result in duties. Economists now recognize that the prospect of protection imposes additional costs on the domestic economy and on the international trading community.

Under existing rules, firms and/or industries can alter their decisions in order to improve the chance of receiving AD protection at some future date. The concept of "strategic decisionmaking" must be broadened in order to capture the ability of firms to influence potential government decisions. Changes in sales strategies (e.g., pricing and production) and in resource allocation decisions (e.g., employment and capacity) can dramatically change the likelihood of

against countries that are important export markets and U.S. agencies are less likely to rule affirmative against WTO members that have recourse to dispute settlement procedures.

${ }^{9}$ Other studies of U.S. AD determinations include Finger, Hall and Nelson (1982), Baldwin (1985), Moore (1992), Keith Anderson (1993), and Baldwin and Steagall (1994). Studies of EU AD decisions include Tharakan (1991), Tharakan and Waelbroeck (1994) and Eymann and Schuknecht (1996).

${ }^{10}$ See Miyagiwa and Ohno (1995) for this general argument. Crowley (2002) examines the relative incentives to innovate under AD protection that targets only certain import sources versus safeguard (or "escape clause") trade protection that provides relief from all import sources. 
$\mathrm{AD}$ protection. What this means is that $\mathrm{AD}$ may be imposing costs in sectors that are unencumbered by duties.

Most observers would agree that interested parties influenced traditional tariff policies via lobbying, log-rolling efforts, and general rent-seeking activity. There should be no debate, however, that the channels of influence are much more explicit under administered protection laws. ${ }^{11}$ An advantageously timed plant closing (signaling injury) or plant opening (signaling vulnerability to imports), worker layoff and/or reduction in hours, excess inventory build-up, etc. can all improve a domestic industry's chance of winning protection. On the other hand, decisions by foreign firms to maximize short-run profits, say, by naively pricing-to-market or perhaps bidding for a larger than normal export contract, can have disastrous long-run consequences if such actions result in the imposition of $\mathrm{AD}$ duties.

It is our view that one of the most important insights of the recent AD literature is that the mere presence of $\mathrm{AD}$ law can affect the behavior of firms and hence market outcomes, even if AD duties are never imposed. Papers in this literature show that this phenomenon can lead to a wide variety of outcomes, some obviously unintended and even perverse to the likely objectives of $\mathrm{AD}$ protection. A crucial feature of $\mathrm{AD}$ law that creates these incentives for strategic behavior on the part of firms is the use of established criteria based on prior market outcomes to make AD case determinations. This allows relevant firms to act strategically to influence AD outcomes. In other words, $\mathrm{AD}$ trade protection is endogenous with respect to firms' decisions.

There are two main strands in the literature studying the impacts of the endogeneity of $\mathrm{AD}$ protection. The first and larger strand of the literature encompasses models of how AD distorts non-cooperative outcomes. The second strand of the literature studies how AD induces

\footnotetext{
${ }^{11}$ There is, for instance, a large literature dating back at least to Bhagwati (1982) on directly unproductive profit seeking (DUP) activity; one example of DUP is lobbying for protection.
} 
cooperative outcomes. In this review, we will focus on the former. Those interested in the latter should consult Blonigen and Prusa (2001) and the references therein.

To our knowledge, all of the "non-cooperative" outcome literature models the link between decisions and the prospect of protection as internal to the firm. That is, the actions taken by a firm (or firms) directly influences economic indicators that the government considers when making its determination whether or not to levy AD duties. A potentially useful, but as of yet unexplored, alternative would be to model the link as external to any one firm in the industry. This alternative may be valuable because the GATT/WTO AD statute requires governments to consider the industry's health. It is a rare case where the domestic and/or foreign industry is sufficiently concentrated to think that the actions by any one firm measurably alters the government's calculus.

Given the assumption that the impact is internal to the firm, it is natural that these papers rely on models of imperfect competition (often, oligopoly models) in games of at least two stages, where the focus is on firms' first-stage choices of a strategic variable, such as price, quantity, or quality. The existing literature most often assumes the economic indicator that government authorities consider is domestic profits. This is a reasonable starting place as our review of $\mathrm{AD}$ statutes indicates that every government considers domestic profitability as a signal of injury (Steele, 1996; Santos 1998).

In general, the economic structure of the papers in this literature can be written as

$$
\begin{aligned}
& \pi_{1}^{i}\left(a_{1}^{1}, a_{1}^{2}, a_{1}^{3}, \ldots, a_{1}^{n} ; a_{0}^{1}, a_{0}^{2}, a_{0}^{3}, \ldots, a_{0}^{n} ; S_{1}, V_{1}\right) \\
& \quad+\delta E \pi_{2}^{i}\left(a_{2}^{1}, a_{2}^{2}, a_{2}^{3}, \ldots, a_{2}^{n} ; a_{0}^{1}, a_{0}^{2}, a_{0}^{3}, \ldots, a_{0}^{n}, S_{2}, V_{2}, A D D\right), \quad i=1,2,3 \ldots, n, \\
& A D D=f\left(a_{1}^{1}, a_{1}^{2}, a_{1}^{3}, \ldots, a_{1}^{n} ; a_{0}^{1}, a_{0}^{2}, a_{0}^{3}, \ldots, a_{0}^{n}, S_{1}, V_{1}\right), \\
& V_{2}=g\left(a_{1}^{1}, a_{1}^{2}, a_{1}^{3}, \ldots, a_{1}^{n}, a_{2}^{1}, a_{2}^{2}, a_{2}^{3}, \ldots, a_{2}^{n} ; a_{0}^{1}, a_{0}^{2}, a_{0}^{3}, \ldots, a_{0}^{n}, S_{1}, S_{2}, A D D\right)
\end{aligned}
$$


where $\pi_{\mathrm{t}}^{\mathrm{i}}$ denotes firm $i$ 's profits in period $t$. and $\delta$ is the discount factor. For notational convenience we use superscripts to denotes firms and subscripts to denote time periods. Firms earn profits in periods one and two $(t=1,2)$. In the second period the expectation is taken with respect to the $\mathrm{AD}$ duty, $\mathrm{ADD}$.

While this set-up is more general than that used in any single paper, its general structure encompasses the modeling strategy of virtually the entire literature. In this set-up we allow for $n$ firms, where we imagine that a subset of the firms are domestic and the rest are foreign. In most of the literature $n=2$, where one firm is domestic and other is foreign.

The profits in each period are influenced by the actions of each firm, $a_{t}^{i}$. Depending upon the application, one could model that firms setting prices, quantities, the total number of workers, lobbying expenditures, etc., to maximize long-run profits. We allow for the possibility that $a_{t}^{i}$ is a vector, implying that firms can make more that one action choice in each period. For instance, the firms might choose product quality and price. Subsequent market realizations will determine whether duties will be levied. We also allow for the possibility that firms take actions in period zero that influence later decisions. For instance, all firms might make quality choices in period zero and then in periods one and two compete in prices or quantities for profits.

It is typical in the literature to also allow the profits in each period to be affected by a random shock or "state of the world," $S_{t}$, by which one might mean an exchange rate shock, demand shock, or perhaps the underlying political sentiment for protection. It is usually assumed that the random shock in period $t$ is realized after period $t$ actions are taken.

In the second period the firms' profit may be affected by an AD duty (ADD) imposed between period one and period two. Finally, since AD actions and voluntary export restraints are 
often related, we also include the possibility that profits in period $t$ might be influenced by a VER on a subset of the firms $\left(V_{t}\right)$.

The key insight that all the papers examine is the interplay between actions, states of the world, VERs, and AD duties. AD duties are endogenous in the sense that for at least some realizations of $S_{t}$, the action taken by firm $i$ can increase or decrease the chance of an AD duty in period 2 (or perhaps a VER in period 2).

One of the first papers in this literature, Leidy and Hoekman (1990) examines the production decisions of a single exporting firm with some degree of market power that faces possible AD protection against its exports and random exchange rate shocks. ${ }^{12}$ The firm is assumed to have to make its production decision before the exchange rate is known. A key issue in the paper, which will also be important for other papers discussed below, is how the AD authorities calculate the dumping margin. As mentioned earlier, one method often used is to define the dumping margin as the difference between the exporting firm's home price and its export price. Leidy and Hoekman (1990) call this "price-based AD law." A second alternative often used is a "cost-based" method where the dumping margin is the difference between a firm's (estimated) cost of production and its export price. Leidy and Hoekman (1990) show an important difference in the exporting firms optimal behavior to avoid an AD duty when having to adjust prices due to an adverse exchange rate shock. Under price-based AD law the firm can re-equalize prices after an exchange rate shock by both decreasing supply to raise prices in its export market and increasing supply (or dumping) to lower prices in its own home market, whereas, under cost-based AD law, adjustment must come from the supply to the export market only.

\footnotetext{
${ }^{12}$ In the context of the above model, the Leidy and Hoekman model can best be thought of as setting $n=1$. They model the foreign firm competing against a competitive domestic market.
} 
Thus, we take two main messages from Leidy and Hoekman (1990). First, the prospect of $\mathrm{AD}$ protection increases exchange rate risk and foreign firms manage this risk by reducing export sales. Second, export restraint will likely be larger when AD authorities use cost-based methods. This in turn implies that the relief to domestic producers in the export market from AD protection may be largest when AD authorities use cost-based methods. Given Leidy and Hoekman's findings, it appears that the threat of cost-based investigations has a bigger chilling effect on trade than the threat of price-based investigations.

Ethier and Fischer (1987), Fischer (1992) and Reitzes (1993) broaden the focus on strategic behavior by examining oligopoly games involving both a foreign and domestic firm. In the context of the above general model, these papers set $n=2$ and model the actions as firms setting prices or quantities. These papers examine two-stage duopoly games (both in prices and quantities), where firms compete in the first stage and a government authority imposes trade protection based on market outcomes in the second stage. There is no modeling of VERs and no period zero actions.

The primary focus in these papers is on the first stage, where the firms strategically alter behavior to influence the second-stage $\mathrm{AD}$ outcome. Like Leidy and Hoekman, one result is that the foreign firm tries to lessen the chance of trade protection, but an additional insight is that the domestic firm will act to make trade protection more likely. Interestingly, and perhaps frustratingly, these incentive effects could lead to just about any combination of distorted market effects, depending on the characteristics of the strategic game being played by the firms.

For example, the actual market outcomes that occur based on these incentives differ significantly depending on whether the oligopoly game is in prices or quantities. Assuming a price-based method of determining the dumping margin, a domestic firm may increase output in 
a Cournot game to drive down the common price in the domestic market, while the foreign firm decreases its exports to the domestic market. This could actually improve welfare in the domestic market if the net effect is greater competition. ${ }^{13}$ Under price competition, however, the foreign firm alone determines its export price that is the basis for the dumping margin calculation. Thus, foreign firms may have incentives to raise price and, if the goods are imperfect substitutes, the domestic firm may then raise prices as well, which would hurt domestic welfare. We stress the word "may" in the previous sentences because, as Fischer (1992) shows, even these results may be reversed for various games of price or quantities, depending on other market conditions. In addition, a wider variety of outcomes occur if one considers a game in prices with perfectly substitutable goods, as in Reitzes (1993), or if one examines these games when the dumping margin is calculated using a cost-based approach, as analyzed by Fischer (1992).

An important omission of these papers is consideration of the injury determination in AD cases. Firms likely have incentives to not only manipulate the dumping margin, but also the injury determination. In fact, given the evidence on the effect of exchange rates on AD filings discussed above, the injury determination may be more important. Prusa (1994) and Pauwels et al. (2001) examine this with respect to U.S. and EU AD law, respectively. In the context of the above general model, these papers are very much like the preceding set of papers (i.e., $n=2$, actions modeled as prices or quantities, no modeling of VERs, no period zero actions) except that process by which $\mathrm{AD}$ duties are determined (the $f\left({ }^{\prime}\right)$ function) captures both the LTFV and injury determinations.

\footnotetext{
${ }^{13}$ Reitzes (1993) shows that this requires that the foreign firm's share of the domestic market needs to be sufficiently small for this to occur.
} 
The additional insight from these papers is that the two considerations of dumping and injury may give the firms exactly opposite incentives to alter strategic variables. For example, while a domestic firm may want to increase output due to the dumping margin calculation in a game of quantities, they will have incentives to lower output to make an injury determination more likely. ${ }^{14}$ Prusa also shows that the threat of AD protection creates a de facto price floor, below which foreign firms will not price because doing so inordinately increases the chance of protection.

Hillman et. al. (1987) model the action set as employment. They argue that the greater an industry's layoffs the more likely will the authorities levy AD duties. As a result, firms hire an excessive number of workers. In the context of the general model set-up, firms overhire in period zero and then layoff some of the excess workers in period one in order to strengthen their injury claim. The important insight is that resource allocation decisions now have an insurance function --- labor and capital do not merely translate into output but also influence the prospect of future protection.

Several other papers have explored the interaction between the threat of AD protection and voluntary export restraints (VERs). An important modeling question is whether the prospect of a VER affects dumping and $\mathrm{AD}$ outcomes or whether the threat of $\mathrm{AD}$ duties induces firms to negotiate a VER in an effort to forestall the case. Anderson (1992; 1993) examines the case when causality runs from VERs to AD duties. In the papers discussed above, the AD process is broken into two stages. In the first stage, firms pick strategic variables that then impact the AD case outcome in a second stage. Based on the observation that many US AD investigations have led to VERs, Anderson adds an additional stage to this model of the AD process: the possibility of a negotiated VER after an AD case has been initiated. In practice, VERs are administered so

\footnotetext{
${ }^{14}$ Leidy (1994) summarizes most of this early work.
} 
that foreign firms receive the quota rents and these rents are based on the market shares of the foreign firms. These features lead to the possibility of a perverse market outcome called “domino dumping." In pursuit of quota rents from VERs based on market shares, foreign firms are encouraged by the trade protection policies to dump in order to start an AD investigation that will lead to a VER. ${ }^{15}$

Kolev and Prusa (forthcoming, 2002) examine what can occur when causality runs from AD to VERs. In addition, Kolev and Prusa model the AD statute using the cost-based approach and further make the realistic assumption that $\mathrm{AD}$ authorities have incomplete information on foreign firms' costs. Because of the information problem, Kolev and Prusa find that efficient foreign firms pool with less efficient foreign firms and voluntarily restrain their exports (i.e., a VER in period one, $V_{l}$ ). This then leads the $\mathrm{AD}$ authorities to impose AD duties that are undesirably low (from the standpoint of the domestic producers) for efficient foreign firms and too high for inefficient foreign firms.

Blonigen and Ohno (1998) present another reason why the presence of AD law may actually encourage dumping on the part of foreign firms. They present an oligopoly model where foreign firms have different abilities to tariff jump AD protection in an export market. One possible outcome in the model is "protection-building trade" where a foreign firm dumps to elicit AD duties against all foreign firms in the industry ${ }^{16}$, and then tariff jumps into a market that is protected against exports from other foreign rivals that do not tariff jump. They present a few US AD case studies that are suggestive of protection building trade behavior.

\footnotetext{
${ }^{15}$ We note that the timing of the AD case and VER in Anderson $(1992,1993)$ contrasts with that in Kolev and Prusa (forthcoming). This is not necessarily inconsistent in that there is evidence in these papers from U.S. cases of the timing of the AD case and VER occurring in both possible sequences. In addition, a VER occurring before an AD case may not always be publicly announced or noticed.

${ }^{16}$ Blonigen and Ohno (1998) detail how the administration of AD law often lead to AD duties across many related import sources, not just the primary dumping sources.
} 
While all the papers in this section examine how price or quantity decisions may be affected by the presence of AD law, Vandenbussche and Wauthy (2001) how firms' product quality choices may be affected. They analyze a model of vertical product differentiation between a domestic and foreign firm, where firms first choose quality and then choose prices. They show that if a price undertaking is the anticipated outcome from application of the EU AD law, the foreign firm will be more aggressive in the quality game to have a higher quality than the domestic firm. The rationale is that price undertakings require the foreign firm to match the price of the domestic firm, which they will not be able to do and still compete in the market if they have the low quality product. Thus, AD law may reverse which firm "wins" the quality game and ultimately lead to lower welfare for the home country.

On a final note, given the nature of the issue, papers in this literature are almost exclusively theoretical: it's difficult to observe and measure how market outcomes are altered from the mere presence of $\mathrm{AD}$ law. One exception is an early paper by Herander and Schwartz (1984). The paper first estimates the probabilities of an AD filing and of an affirmative injury decision using data on US AD filings from 1976 through 1981. These probabilities are then specified as independent regressors in an equation explaining dumping margins over this period. The paper's testing hypothesis is that increased threats of AD duties (proxied by the two probabilities of case filing and injury determination) will lead to foreign firms altering their prices to avoid such an outcome and, hence, lower dumping margins. The paper finds mixed support for the hypotheses, which is likely due to a number of factors, including a limited time frame, insufficient methods to deal with endogeneity of the equations, and sample selection issues of focusing only on the pricing behavior of the firms that were involved in $\mathrm{AD}$ 
investigations. Nevertheless, the paper provides a useful insight into how empirical testing in this area may proceed in the future.

\section{Conclusion.}

$\mathrm{AD}$ is the most widely used instrument of administered protection. Developed economies like the U.S., EU and Australia have long used AD in order to reduce import competition from more efficient foreign competitors. In the past decade these traditional users have been joined by a large and growing number of new users. What is worrisome is that many of these new users are even more capricious in their implementation than the traditional users.

In this paper we hope to draw greater attention to the costs of $\mathrm{AD}$ protection. AD duties are the most easily measured and most visible cost of AD protection. We hope the approach of Gallaway, et. al. (1999) provides guidance to other researchers on measuring the cost of AD protection. The retrospective nature of the administrative review process leads to much more adverse welfare consequences by allowing foreign firms to capture foreign rents at the expense of US tariff revenue. It is unfortunate that as of the current time we do not have a widespread understanding of the costs of $\mathrm{AD}$ duties. This is an obvious research topic that we urge researchers and graduate students to tackle. The benefits of such efforts are potentially quite large, especially in light of the fact that antidumping is on the agenda for the Doha Round of the WTO. The efforts of those interested in reining in AD abuses can only be strengthened with more evidence on the costs of $\mathrm{AD}$ protection.

In addition, we have emphasized that the effects of $\mathrm{AD}$ actions are not summarized by the $\mathrm{AD}$ duty one observes. The $\mathrm{AD}$ literature to date has taken this general observation and established a whole set of results that shows that what one sees with AD trade protection is far 
from what one gets. There is a substantial literature that shows the mere presence of AD law, with its established rules for determining outcomes, alters incentives for market participants. Thus, a wide variety of potentially distorted market outcomes have been discovered. What is unknown, however, is the cost of such machinations. This is an important area of future research that we look forward to reading (and perhaps writing!). 


\section{References}

Anderson, James E., "Domino Dumping I: Competitive Exporters," American Economic Review 82 (1992): 65-83.

Anderson, James E., "Domino Dumping II: Anti-dumping," Journal of International Economics 35 (1993): 133-50.

Anderson, Keith B. (1993) "Agency Discretion or Statutory Direction: Decision Making at the U.S. International Trade Commission," Journal of Law and Economics, Vol. 36(2): 915-35.

Areeda, Phillip E. and David F. Turner, "Predatory Pricing and Related Practices Under Section 2 of the Sherman Act" Harvard Law Review 88 (1975): 697-733.

Baldwin, Robert E. and Jeffrey W. Steagall, "An Analysis of ITC Decisions in Antidumping, Countervailing Duty and Safeguard Cases," Weltwirtschaftliches Archiv 130 (1994): 290308.

Baldwin, Robert E., The Political Economy of US Import Policy. Cambridge: The MIT Press, 1985.

Bhagwati, Jagdish N. (1982) “Directly Unproductive, Profit-seeking (DUP) Activities,” Journal of Political Economy, Vol. 90 (5), 988-1002.

Blonigen, Bruce A. and Thomas J. Prusa, “Antidumping," in James Harrigan (ed.), Handbook of International Trade, Oxford and Cambridge: Blackwell Publishers, forthcoming 2001.

Blonigen, Bruce A. and Yuka Ohno, "Endogenous Protection, Foreign Direct Investment, and Protection-building Trade,” Journal of International Economics 46 (1998):205-27.

Blonigen, Bruce A., and Chad P. Bown, "Antidumping and Retaliation Threats," NBER Working Paper No. 8576, 2001.

Clarida, Richard H., "Dumping in Theory, in Policy, and in Practice," in Jagdish Bhagwati and Robert Hudec (eds.), Fair Trade and Harmonization, Cambridge: The MIT Press, 1996.

Crowley, Meredith A., Do Safeguard Tariffs and Antidumping Duties Open or Close Technology Gaps?, Mimeo, 2002.

DeVault, James M., "The Welfare Effects of US Antidumping Duties," Open Economies Review 7 (1996): 19-33.

Ethier, Wilfred J. and Ronald D. Fischer, "The New Protectionism," Journal of International Economic Integration 2 (1987):1-11.

Eymann, Angelika and Ludger Schuknecht, "Antidumping Policy in the European Community: Political Discretion or Technical Determination?” Economics and Politics 8 (1996):111-31.

Feenstra, Robert C., "How Costly is Protectionism?" Journal of Economic Perspectives 6 (1992): 159-78.

Feinberg, Robert M. and Seth Kaplan, "Fishing Downstream: The Political Economy of Administered Protection," Canadian Journal of Economics 26 (1993):150-58.

Finger, J. Michael., H. Keith Hall, and Douglas R. Nelson, “The Political Economy of Administered Protection," American Economic Review 72 (1982):452-66.

Fischer, Ronald D., "Endogenous Probability of Protection and Firm Behavior," Journal of International Economics 32 (1992):149-63.

Gallaway, Michael P., Bruce A. Blonigen, and Joseph E. Flynn, "Welfare Costs of US Antidumping and Countervailing Duty Laws," Journal of International Economics 49 (1999):211-44. 
Hansen, Wendy L. and Thomas J. Prusa, "The Economics and Politics of Trade Policy: An Empirical Analysis of ITC Decision Making," Review of International Economics 5 (1997):230-45.

Hansen, Wendy L. and Thomas J. Prusa., "Cumulation and ITC Decision Making: The Sum of the Parts is Greater than the Whole," Economic Inquiry 34 (1996):746-69.

Hartigan, James C., Sreenivas Kamma, and Philip R. Perry, "The Injury Determination Category and the Value of Relief from Dumping," Review of Economics and Statistics 71 (1989): 18386.

Herander, Mark G. and J. Brad Schwartz, "An Empirical Test of the Impact of the Threat of US Trade Policy: The Case of Antidumping Duties," Southern Economic Journal 51 (1984): 5979.

Hillman, Arye, Eliakim Katz, and Jacob Rosenberg. (1987) "Workers as insurance: Anticipated government assistance and factor demand," Oxford Economic Papers, Vol. 39, 813-20.

Horlick, Gary N. (1989). “The United States Antidumping System,” in Jackson, John H. and Edwin A. Vermulst, eds., Antidumping Law and Practice, (Ann Arbor, MI: The University of Michigan Press).

Hughes, John S., Stefanie Lenway, and Judy Rayburn, "Stock Price Effects of US Trade Policy Responses to Japanese Trading Practices in Semi-conductors," Canadian Journal of Economics 30 (1997): 922-42.

Kelly, Kenneth A., and Morris E. Morkre, "Do Unfairly Traded Imports Injure Domestic Industries?" Review of International Economics 6 (1998):321-32.

Kolev, Dobrin, and Thomas J. Prusa, "Dumping and Double Crossing: The (In)Effectiveness of Cost-Based Trade Policy Under Incomplete Information,” International Economic Review, forthcoming 2002.

Leidy, Michael P. (1994) "Trade Policy and Indirect Rent Seeking: A Synthesis of Recent Work," Economics and Politics. Vol. 6(2): 97-118.

Leidy, Michael P. and Bernard M. Hoekman., "Production Effects of Price- and Cost-based Antidumping Laws Under Flexible Exchange Rates," Canadian Journal of Economics 23 (1990):873-95.

Lindsey, Brink, “The US Antidumping Law: Rhetoric versus Reality," CATO Institute Center for Trade Policy Studies Working Paper No. 7, 1999.

Mahdavi, Mahnaz, and Amala Bhagwati, "Stock Market Data and Trade Policy: Dumping and the Semiconductor Industry," International Trade Journal 8 (1994):207-21.

Messerlin, Patrick A., "The EC Antidumping Regulations: A First Economic Appraisal, 198085," Weltwirtschaftliches Archiv 125 (1989):563-87.

Miyagiwa, Kaz, and Yuka Ohno, "Closing the Technology Gap under Protection," American Economic Review 85 (1995): 755-70.

Moore, Michael O. (1992). "Rules or Politics? An Empirical Analysis of ITC Anti-dumping Decisions," Economic Inquiry, Vol. 30(3): 449-466.

Morkre, Morris E. and Kenneth H. Kelly, "Effects of Unfair Imports on Domestic Industries: US Antidumping and Countervailing Duty Cases, 1980-1988”, Federal Trade Commission Bureau of Economics Staff Report, 1994.

Murray, Tracy, and Donald J. Rousslang, "A Method for Estimating Injury Caused by Unfair Trade Practices," International Review of Law and Economics 9 (1989):149-64. 
Pauwels, Wilfred, Hylke Vandenbussche and Marcel Weverbergh, "Strategic Behaviour under European Antidumping Duties," International Journal of the Economics of Business 8 (2001):79-103.

Prusa, Thomas J. and Susan Skeath, "The International Use of Antidumping: Unfair Trade or Tit-for-Tat?," NBER Working Paper No. 8424, 2001.

Prusa, Thomas J., "On the Spread and Impact of Antidumping," Canadian Journal of Economics 34 (2001):591-611.

Prusa, Thomas J., "Pricing Behavior in the Presence of Antidumping Law," Journal of Economic Integration 9(1994):260-89.

Reitzes, James D., “Antidumping Policy,” International Economic Review 34 (1993):745-63.

Santos, L. E., (ed.) (1998). The Compendium of Foreign Trade Remedy Laws, Washington, D.C., The American Bar Association.

Steele, Keith (ed.), Antidumping Under the WTO: A Comparative Review, London: Kluwer, 1996.

Tharakan, P.K.M. and J. Waelbroeck, "Antidumping and Countervailing Duty Decisions in the E.C. and in the US: An Experiment in Comparative Political Economy," European Economic Review 38 (1994):171-93.

Tharakan, P.K.M., "The Political Economy of Anti-dumping Undertakings in the European Communities," European Economic Review 35 (1991):1341-59.

US International Trade Commission, "The Economy-Wide Effects of Outstanding Antidumping and Countervailing Duty Orders," in US International Trade Commission, The Economic Effects of Antidumping and Countervailing Duty Orders and Suspension Agreements, Washington, DC: US International Trade Commission, 1995.

Vandendenbussche, Hylke and Xavier Wauthy, "Inflicting Injury Through Product Quality: How EU Antidumping Policy Disadvantages European Producers," European Journal of Political Economy 17 (2001): 101-16.

Viscusi, W. Kip, John M. Vernon, and Joseph E. Harrington, Jr. Economics of Regulation and Antitrust, Second Edition. Cambridge, MA: The MIT Press, 1995. 